\title{
Melanocytic Malignant Peripheral Nerve Sheath Tumor of the Male Breast
}

\author{
Haijun Wang ${ }^{\mathrm{a}}$ Jing Ge ${ }^{\mathrm{b}}$ Lirong Chen ${ }^{\mathrm{a}}$ Panpan $\mathrm{Xie}^{\mathrm{c}}$ Fangfang Chen ${ }^{\mathrm{c}}$ Yiding Chen ${ }^{\mathrm{c}}$ \\ ${ }^{\text {a }}$ Department of Pathology, \\ ${ }^{\mathrm{b}}$ Department of Oral Medicine, \\ 'Department of Surgical Oncology, The Second Affiliated Hospital, Zhejiang University College of Medicine, Hangzhou, Zhejiang, China
}

\section{Key Words}

Malignant peripheral nerve sheath tumor - Breast . Melanocytic

\section{Summary}

Background: Malignant peripheral nerve sheath tumors are rare tumor entities that originate from peripheral nerve sheaths and have an unfavorable prognosis. Common sites include deeper soft tissues, usually in the proximity of a nerve trunk. Breast is an absolutely rare location of this lesion, and presentation as a breast lump in the male breast is even rarer. Case Report: A 65-year-old man presented with a 6-month history of a painless mass of the left breast. Tissue biopsy was performed. Histopathology revealed a malignant spindle cell tumor which was confirmed to be a melanocytic malignant peripheral nerve sheath tumor on the basis of immunopositivity for HMB45 and S-100. Conclusion: There are no generally accepted guidelines for the treatment of malignant peripheral nerve sheath tumors in the male breast. The patient was referred for radiation therapy after simple mastectomy.

\section{Introduction}

The term 'malignant peripheral nerve sheath tumor' (MPNST) comprises various entities including malignant schwannoma, neurofibrosarcoma, and neurogenic sarcoma. MPNSTs are

\author{
Schlüsselwörter \\ Maligner peripherer Nervenscheidentumor · Brust \\ Melanozytär
}

\section{Zusammenfassung}

Hintergrund: Maligne periphere Nervenscheidentumoren sind seltene Tumorentitäten, die ihren Ursprung in peripheren Nervenscheiden haben und eine ungünstige Prognose aufweisen. Häufige Tumorlokalisationen sind tiefere Weichgewebe, gewöhnlich in der Nähe eines Nervenstamms. Die Brust ist eine äußerst seltene Lokalisation, und das Auftreten in Form von Tumoren der männlichen Brust ist noch seltener. Fallbericht: Ein 65-jähriger Mann wurde mit einer 6-monatigen Vorgeschichte eines schmerzlosen Knoten in der linken Brust vorstellig. Die histopathologische Untersuchung von Gewebebiopsien ergab einen malignen Spindelzelltumor, welcher basierend auf Immunpositivität für HMB45 und S-100 als ein melanozytärer maligner peripherer Nervenscheidentumor identifiziert wurde. Schlussfolgerung: Es bestehen keine allgemein anerkannten Richtlinien für die Behandlung maligner peripherer Nervenscheidentumoren der männlichen Brust. Der Patient wurde nach einfacher Mastektomie radiotherapeutisch behandelt.

\section{KARGER}

Fax +497614520714

Information@Karger.de

www.karger.com (c) 2009 S. Karger GmbH, Freiburg rare with an incidence of 1:100,000 [1]. MPNSTs behave aggressively, with a high rate of local recurrence and a propensity to metastasize. The optimal treatment is resection, and the role of adjuvant treatment is unclear. We report a rare case of MPNST in the male breast. 


\section{Case Report}

A 65-year-old male patient presented to the Surgical Oncology Department with complaints of a rapidly growing left breast lump for 6 months. There was no history of a prior breast mass, pain, trauma, or a family history of breast cancer. On examination, a left breast mass measuring approximately $2 \times 2 \times 3 \mathrm{~cm}$ was evident. The lesion was painless, solid, and fixed. There was no retraction or ulceration of the overlying skin. Extensive examination showed there were no subcutaneous swelling, café au lait spots, or Lisch nodules, thus ruling out underlying neurofibromatosis. An excisional biopsy was advised to confirm the diagnosis and to guide further management. Grossly, the specimen was a skin covered lumpectomy specimen measuring $3 \times 3 \times 4 \mathrm{~cm}$. The cut sections revealed a firm infiltrative unencapsulated gray white tumor measuring $2 \times 2 \times 2.6 \mathrm{~cm}$. There were no slit-like areas, areas of hemorrhage, necrosis, or calcification. Hematoxylin-eosin (H\&E) staining demonstrated tumor tissue with spindled epithelioid cells (fig. $1 \mathrm{~A}$ ) some of which contained melanin (fig. $1 \mathrm{~B})$. The cells were arranged in nest-like clusters with a heterogeneous appearance. Immunohistochemically, strong expression of vimentin and S-100 was demonstrated (fig. 1 C). The pigmented cells were positive for HMB45 (fig. 1 D). There was no immunoreaction to cytokeratin (CK)-8, or neurofilament (NF). The histological diagnosis of MPNST was based on the demonstration of spindled cells and their arrangement, the pattern of immunoreactions, and the electron microscopy investigation.

\section{Discussion}

For diagnosis of an MPNST, at least one of the following criteria should be fulfilled [2]: i) the tumor arises from a peripheral nerve; ii) the tumor arises from a preexisting benign or other MPNST; iii) the tumor displays histological features of Schwann or perineurial cell differentiation as revealed by immunohistochemistry or electron microscopy. MPNSTs represent approximately $10 \%$ of all soft tissue sarcomas [3], and commonly arise in adult patients ranging from 20 to 50 years of age. They originate from a major or minor peripheral nerve branch or its sheath. Common sites of origin include the extremities and trunk, usually sciatic nerve, brachial plexus, and the sacral plexus. Most cases average more than $5 \mathrm{~cm}$ in diameter [1]. They may arise spontaneously, although in 5-42\% of cases an association with neurofibromatosis (NF) type 1 is known. Deeper neurofibromas are more likely to undergo malignant transformation than their superficial counterparts in NF type 1 [4]. MPNST of the breast is very rare and has been reported only three times in the English literature [57]. As for the male breast, we hereby report the first case of MPNST.

The histological diagnosis of MPNST requires careful differentiation from a number of tumor entities with similar histological features. The spindled type must be carefully differentiated from other spindled-cell soft tissue tumors, in particular fibrosarcoma. An immunoreaction to S-100 as in our case excluded a fibrosarcoma and underlined the close association of MPNST with the nerve sheaths [8]. Another tumor to be considered in the differential diagnosis in our patient was malignant melanoma, because some cells were found to contain melanin on microscopic inspection. However, a malignant melanoma could be excluded because there was no immunoreaction to CK-8 which is only expressed in some epithelioid variants of melanoma. Nevertheless, evidence of a basal lamina by electron microscopy investigation strongly indicated the tumor to be a MPNST by nerve sheath origin. In the case presented here, the tumor was further characterized as a melanocytic MPNST because the melanin-containing cells were found to be positive for HMB45. Since most MPNSTs have poor 5-year survival rates, the patient was referred for radiation therapy after simple mastectomy.
Fig. 1. A H\&E staining, with polymorphic, spindled cells in nest-like clusters $(\times 20)$. B H\&E staining, melanin within epithelioid cells $(\times 20)$. C Positive immunoreaction against S-100 $(\times 20)$; cells are diffusely positive for S-100. D Positive immunoreaction against HMB45 (×20).

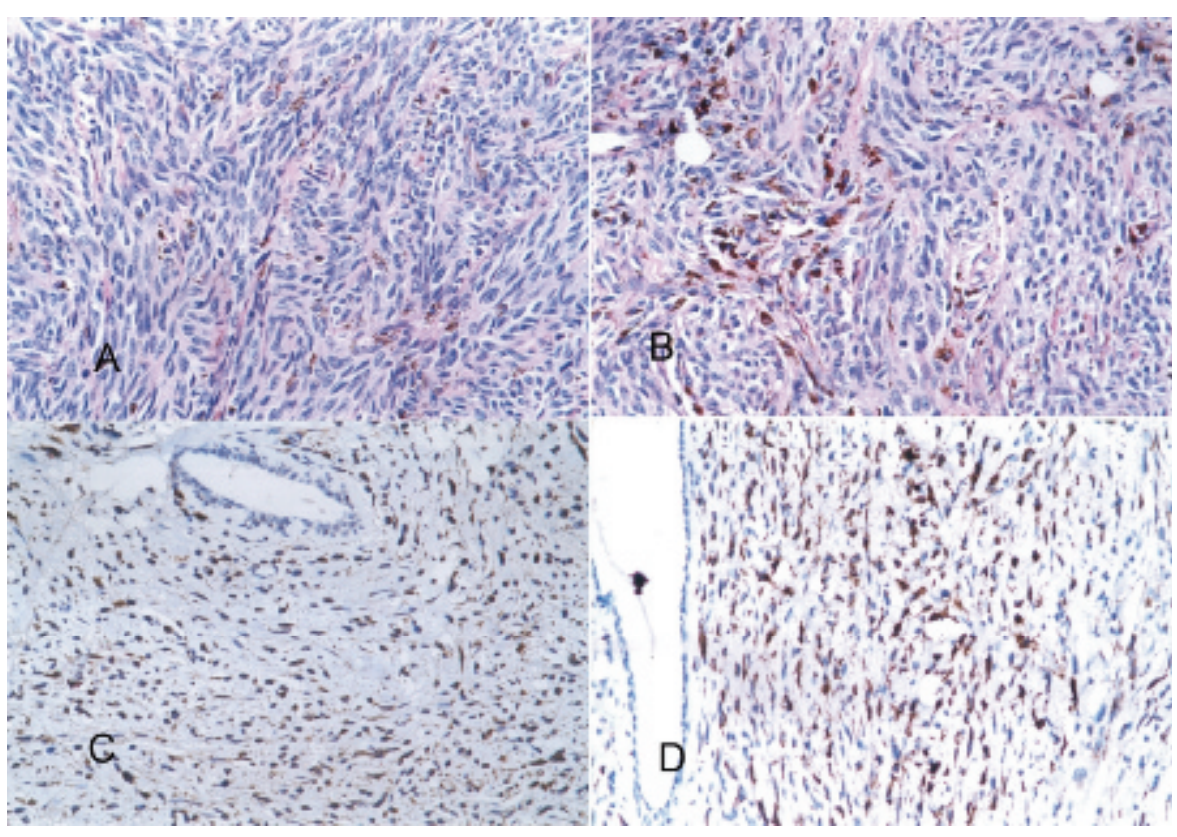

Breast Care 2009;4:260-262 


\section{Acknowledgement}

Written consent was obtained from the patient for publication of this case report. We are thankful to the patient for his cooperation which was of utmost importance to the study.

\section{Conflict of Interest}

We declare that we have no conflict of interest.

\section{References}

1 Ducatman BS, Scheithauer BW, Piepgras DG, Reiman HM, Ilstrup DM: Malignant peripheral nerve sheath tumors. A clinicopathologic study of 120 cases. Cancer 1986;57:2006-2021.

2 Huang L, Espinoza C, Welsh R: Malignant peripheral nerve sheath tumor with divergent differentiation, Arch Pathol Lab Med 2003;127:147-150.

3 Weiss SW, Goldblum JR: Malignant tumors of the peripheral nerves; in Strauss M, Grey L (eds) Enzinger and Weiss's Soft Tissue Tumors (4th ed) St. Louis, Mosby, 2001, pp.1209-1264.
Ferner RE, Gutmann DH: International consensus statement on malignant peripheral nerve sheath tumors in neurofibromatosis. Cancer Res 2002; 62:1573-1577.

5 Medina-Franco H, Gamboa-Dominguez A, de La Medina AR: Malignant peripheral nerve sheath tumor of the breast. Breast J 2003;9:332.

6 Malas S, Krawitz HE, Sur RK, Uijs RR, Nayler SJ, Levin CV: Von Recklinghausen's disease associated with a primary malignant schwannoma of the breast. J Surg Oncol 1995;59:273-275.
7 Dhingra KK, Mandal S, Roy S, Khurana N: Malignant peripheral nerve sheath tumor of the breast: case report. World J Surg Oncol 2007;5:142-144.

8 Johnson MD, Glick AD, Davis BW: Immunohistochemical evaluation of Leu-7, myelin basic protein, S-100 protein, glial fibrillary acidic protein, and LN3 immunoreactivity in nerve sheath tumors and sarcomas. Arch Pathol Lab Med 1988;112:155-160. 